\title{
Reviewing Disciplinary Sanctions in Sports
}

\author{
Rosmarijn van Kleef*
}

\begin{abstract}
International and national sports federations create, apply and enforce rules in order to regulate their sports. If an associated member or club does not comply with these rules, disciplinary sanctions-such as fines, exclusion from participation in certain matches, or even exclusion from the federation-can be imposed. From the outset, the national or international sports federations create their own regulations and enforce them through an internal-private-sanctioning system. However, in the review of the sanction, national law takes up a prominent place. A federation's decision to impose a sanction can be subject to review either by a national court or in arbitration, for example, before the Court of Arbitration for Sport. The arbitral award, whose goal is to reach a final decision, can nevertheless be challenged before a national court. In the review of disciplinary sanctions, different legal frameworks-the private rules of sports federations and national lawcross each other's paths. The aim of this article is to map out the interrelation between these frameworks by analysing the two different paths that exist for the review of a disciplinary sanction. As the regulation of sport naturally crosses national borders, this analysis is structured using a comparative approach to find out whether there is any coherence at the international level regarding the review of disciplinary sanctions. The countries included in the comparison are England, France, Germany, the Netherlands and Switzerland.
\end{abstract}

\section{Keywords}

Disciplinary Sanctions, Sport, Review, Arbitration, Court of Arbitration for Sport, Comparative Law

\section{Introduction}

International and national sports federations ${ }^{1}$ create, apply and enforce rules in order to regulate their sport. Associated athletes and clubs are required to comply with these

* PhD candidate at the Institute for Private Law, Leiden University (Netherlands) and University of Neuchâtel (Switzerland). The author's doctoral research focuses on the interaction between national private law and the regulations of national and international football associations regarding the liability of football clubs for their supporter's misconduct.

1 A national sports federation is the governing body for sport(s) in a certain country. An international federation governs the sport on a global level and exercises a monopoly position. 
rules, which are laid down in the federations' regulations. If they do not abide by the rules, a disciplinary sanction can be imposed. These sanctions can range from a fine, to the exclusion of participation in certain matches, and in extreme cases even to exclusion from the federation.

The creation and enforcement of the rules that athletes and clubs need to adhere to takes place on different levels. From the outset, the national or international sports federation creates its own regulations and enforces them through an internal-and thus private-sanctioning system. However, in the review of the sanction, rules of national law have a prominent place. The federation's decision to impose a sanction can be subjected to review either by a national court or in arbitration-a form of private dispute resolution. The arbitral award, the goal of which is to reach a final decision, can in turn be challenged before a national court. In the review of disciplinary sanctions, different legal frameworks - the private rules of sports federations and national law-thus cross each other's paths. The aim of this article is to map out the interrelation between these frameworks by analysing the two different paths that exist for the review of a disciplinary sanction.

As the regulation of sport, by its nature, crosses national borders, this analysis is structured using a comparative approach to find out whether there exists any coherence on an international level regarding the review of disciplinary sanctions. The countries chosen for this exercise are the Netherlands, England, Germany, France and Switzerland. ${ }^{2}$ In practice, the latter jurisdiction is especially important, as Switzerland is the seat of the Court of Arbitration for Sport (CAS), as well as of the large majority of international sports federations. ${ }^{3}$ As a result, Swiss law applies to virtually all decisions made by international federations, including the disciplinary sanctions they impose upon athletes or clubs.

This article is structured as follows. Section 2 focuses on the review performed by national courts. When an athlete or club is faced with a disciplinary sanction from its sports federation, this decision can be reviewed in court. In this review, the private regulations of the sports federation, or at least their concrete application, are tested against rules of national law. The scope of review applied in these cases is discussed per country. This is followed by an overview of the review of disciplinary sanctions in arbitration. The regulations of a sports federation can provide that the federation's decisions, including disciplinary sanctions, are to be reviewed in arbitration instead of by

2 The selection is based on the following reasons. In the Netherlands, only very little research has been performed on disciplinary regulations in sports. Both Germany and France were chosen as the legal discourse in these countries is strongly developed thus allowing for a high level of analysis. Finally, England and Switzerland have been chosen for their practical importance. England has played a profound role in the development of organised sports in general and football in particular. Switzerland is home to most international sports federations, including the International Olympic Committee, UEFA and FIFA, which results in the applicability of Swiss law to virtually all decisions made by international federations.

3 The International Association of Athletics Federations (IAAF), which resides in Monaco, being the most notable exception. 
a national court. Although this review technically stays in the private sphere, arbitration proceedings are governed by national private law. The first part of Section 3 analyses the requirements national law sets in regard to this arbitration procedure. The second part of Section 3 discusses the option of challenging the arbitral award by a national court. The analysis includes the requirements and issues related to overturning arbitral awards in general, and awards by the Court of Arbitration for Sport (CAS) specifically.

\section{The scope of review of disciplinary sanctions before national courts}

In principle, whenever a sports federation imposes a sanction, this decision can be challenged before a national court. The primary jurisdiction of the courts can only be ousted when a valid arbitration agreement exists. This situation is discussed in Section 3.

When disciplinary sanctions are reviewed by national courts, the private regulations of sports federations, or at least their concrete application, are tested against rules of national law. This section provides an overview of the scope of this review. In other words, how and under what circumstances can the courts intervene in the decision-making of the federations? The goal is to explore how the interrelation between national law and the enforcement of sports federations' regulations compares between the different legal frameworks.

\subsection{The Netherlands}

In the Netherlands, most cases in which the review of a disciplinary sanction is at issue are brought before the summary proceedings judge (kortgedingrechter) of one of the district courts. Generally, these decisions are not appealed. ${ }^{4}$ The legal basis upon which the review is founded is ambivalent as two different approaches can be discerned. Nevertheless, both approaches require that the claimant has exhausted all available internal appeal measures that the sports federation provides. ${ }^{5}$ An example of such a measure is found in the regulations of the Royal Dutch Football Association (KNVB), which after a sanction is imposed by the disciplinary commission, provides for an internal appeal before the appeals commission. ${ }^{6}$

The first approach has its basis in legal entity law. Based on articles 2:14 and 2:15 of the Dutch Civil Code (BW), a resolution (besluit) of an association's organ can be challenged if it is contrary to the law, the articles of association, an internal regulation

4 R J J Eshuis, N E de Heer-de Lange and B J Diephuis (eds), Rechtspleging Civiel en Bestuur 2010 (WODC 2011) 98 <http://www.cbs.nl/NR/rdonlyres/4C7557DA-0BC6-4D77-BB92-EFAD904970A0/0/2011civielbe stuur2010pub.pdf $>$ accessed 21 April 2014.

$5 \quad$ P L Dijk and T J van der Ploeg, Van Vereniging en Stichting, Coöperatie en Onderlinge Waarborgmaatschappij (5th edn, Kluwer 2007) 150; H J Snijders, C J M Klaassen and G J Meier, Nederlands Burgerlijk Procesrecht (Kluwer 2011) 87.

6 Reglement Tuchtrechtspraak Betaald Voetbal, arts 13-17, <www.knvb.nl> accessed 21 April 2014. 
or if it conflicts with the standards of reasonableness and fairness imposed by article 2:8 BW. ${ }^{7}$ The second approach, which seemingly prevails in practice, is to regard the decisions of the bodies of associations as a binding opinion (bindend advies). ${ }^{8}$ Under Dutch law, the binding opinion is a decision on an uncertainty or dispute taken by a third party. ${ }^{9}$ This legal figure falls under the scope of the contract of settlement, which is governed by article 7:900-910 BW. A binding opinion can be challenged solely on the ground that it would be unacceptable for a party to be bound to it, in connection with the content or the manner of its establishment in the given circumstances, according to standards of reasonableness and fairness. ${ }^{10}$ It should be noted that this formula is almost identical to that contained in article 2:8 BW, which requires the legal entity and those involved in its organisation to act according to the standards of reasonableness and fairness in all their relations. ${ }^{11}$ Regardless of the approach taken, ${ }^{12}$ the ability of the reviewing instance is marginal as it is limited to the assessment of whether the deciding body could reasonably have come to the decision. ${ }^{13}$

\subsection{England}

According to English law, the jurisdiction of the disciplinary bodies of sports associations is generally based on contract. Disciplinary sanctions are therefore to be controlled by the ordinary remedies for breach of contract. ${ }^{14}$ The available remedies depend on the

7 Art 2:14 BW only states that a resolution is null and void when it is contrary to the law or the articles of incorporation. However, in parliamentary debates it has been argued that the norm of art 3:40 BW-the general provision concerning juridical acts that are contrary to the law, public policy or good morals-also applies to resolutions of associations. See C J van Zeben, Parlementaire Geschiedenis van het Nieuw BW. Boek 2. Rechtspersonen (Kluwer 1962) 152.

8 Rechtbank Utrecht (Utrecht District Court), LJN: AC3512, 14 April 1978 reported in (1978) NJ 496; Rechtbank Arnhem (Arnhem District Court), LJN: AH0828, 11 September 1985 reported in (1985) KG 296; Rechtbank Arnhem (Arnhem District Court), LJN: AH3134, 17 May 1990 reported in (1990) KG 193; Rechtbank Utrecht (Utrecht District Court), LJN: AH5649, 9 July 1996 reported in (1996) KG 259; Rechtbank Utrecht (Utrecht District Court), LJN: AY5200, 26 July 2006; Rechtbank Utrecht (Utrecht District Court), LJN: BA1595, 21 March 2007; Rechtbank Zutphen (Zutphen Disctrict Court), LJN: BN1808, 21 July 2010; Rechtbank Utrecht (Utrecht District Court), LJN: BQ6349, 18 May 2011; Rechtbank Zwolle-Lelystad (Zwolle-Lelystad Disctrict Court), LJN: BU4893, 16 November 2011 reported in (2012) RN 19.

9 A C van Schaick, Mr C Asser's Handleiding tot de Beoefening van het Nederlands Burgerlijk Recht, 7-VIII, Bijzondere Overeenkomsten (Kluwer 2012) 170.

10 Art 7:904 BW, which codified the case law rule from Hoge Raad (Dutch Supreme Court), 29 January 1931, reported in (1931) NJ 1317.

11 For an overview of the differences and their consequences, see R H C van Kleef, 'Samenloop Bij de Rechterlijke Toetsing van Tuchtrechtelijke Sancties in de Sport' (2013) 6965 WPNR 161.

12 In case law regarding disciplinary sanctions in sports it is not unusual to see appeals based on both grounds: Rechtbank Utrecht (Utrecht District Court), LJN: BA1595, 21 March 2007; Rechtbank Zutphen (Zutphen Disctrict Court), LJN: BN1808, 21 July 2010; Rechtbank Zwolle-Lelystad (Zwolle-Lelystad Disctrict Court), LJN: BU4893, 16 November 2011 reported in (2012) RN 19.

13 Hoge Raad (Dutch Supreme Court), 2 December 1983 reported in (1984) NJ 583.

14 W Wade and C F Forsyth, Administrative Law (10th edn, OUP 2009) 538-39. 
nature of the right invoked by the claimant and are generally open after internal remedies are exhausted. ${ }^{15}$ Traditionally, in common law, there is a primacy of damages. However, in most sports cases, damages will not be a suitable solution as disciplinary sanctions often have an effect on the eligibility of an athlete or club to participate in competitions. Therefore, an injunction-a court order that requires a party to perform or refrain from performing a particular act-is often a more suitable remedy.

Despite the undisputed contractual basis of the relationship between athletes, clubs and sports federations, ${ }^{16}$ there has been a long-standing debate about whether sports federations are subject to the public law remedy of judicial review, under which the legality of the decision-making process of a body exercising a public function is reviewed, instead of the merits. ${ }^{17}$ This debate was settled in Bradley v Jockey Club. Graham Bradley was a successful steeplechase jockey who was charged with breaching the 'Racing Rules' for allegedly passing racing information to a gambler. The Jockey Club Disciplinary Committee imposed multiple sanctions, including disqualification for a period of eight years. The court developed a so-called private law supervisory jurisdiction.

The function of the court is not to take the primary decision but to ensure that the primary decision-maker has operated within lawful limits. It is a review function, very similar to that of the court on judicial review. Indeed, given the difficulties that sometimes arise in drawing the precise boundary between the two, I would consider it surprising and unsatisfactory if a private law claim in relation to the decision of a domestic body required the court to adopt a materially different approach from a judicial review claim in relation to the decision of a public body. In each case the essential concern should be with the lawfulness of the decision taken: whether the procedure was fair, whether there was any error of law, whether any

15 A Lewis and J Taylor, Sport: Law and Practice (Tottel 2008) 292-93.

16 See R van Kleef, 'The Legal Status of Disciplinary Regulations in Sport' (2014) 14 Intl Sports L J 24, 31-35.

17 Historically, the remedies of administrative law were reserved to authorities whose powers were granted for governmental purposes but over time have been extended to other bodies. However, despite the creation of a broader 'public function test' (in $R v$ Panel on Take-overs and Mergers, ex p Datafin Plc [1987] QB 815), the English courts have held consistently that challenges to actions of sports governing bodies should be brought in private law proceedings and not by way of judicial review. Landmark decision: $R v$ Jockey Club exp Aga Khan [1993] 1 WLR 909. See also $R v$ Football Association of Wales ex p Flint Town United Football Club [1991] COD 44; $R v$ Disciplinary Committee of the Jockey Club ex p Massingberd-Mundy [1993] 2 All ER 207; $R$ v Jockey Club ex $p$ RAM Racecourses Ltd [1993] 2 All ER 225; $R$ v Football Association Ltd ex p Football League [1993] 2 All ER 833. The contractual relationship between a sports federation and its members stands in the way of this remedy. Existing criticism of this case law is mainly based on the fact that the virtually monopolistic powers of national sports federations result in the situation that a person who wishes to practice a certain sport cannot avoid submitting to its jurisdiction. See M J Beloff and T Kerr, 'Why Aga Khan is Wrong' (1996) 1 Judicial Rev 30; D Pannick, 'Judicial Review of Sports Bodies' (1997) 3 Judicial Rev 150. According to Gardiner and others, 'the monopoly positions held by many of these bodies have been acknowledged as being reason enough to supervise their activities': S Gardiner and others, Sports Law (4 ${ }^{\text {th }}$ edn, Routledge 2012) 134. Accordingly, the courts have intervened on multiple occasions to ensure disciplinary bodies apply the minimal standards of natural justice. Davis $v$ Carew-Pole [1956] 1 WLR 883; Lee v Showmen's Guild of Great Britain [1952] 2 QB 329; Modahl v British Athletic Federation Ltd (No 2) [2002] 1 WLR 1192. See also P McCutcheon, 'Sports Discipline, Natural Justice and Strict Liability’ (1999) 28 Anglo-American L R 37, 39; Lewis and Taylor (n 15) 171. 
exercise of judgment or discretion fell within the limits open to the decision-maker, and so forth. ${ }^{18}$

Nevertheless, as in the judicial review procedure, the court's assessment is largely restricted to procedural elements:

The court's role, in the exercise of its supervisory jurisdiction, is to determine whether the decision reached falls within the limits of the decision-maker's discretionary area of judgment. If it does, the penalty is lawful; if it does not, the penalty is unlawful. It is not the role of the court to stand in the shoes of the primary decision-maker, strike the balance for itself and determine on that basis what it considers the right penalty should be. ${ }^{19}$

Since Bradley, it can be argued that sports governing bodies owe broadly the same obligations as a matter of private law as they would if their decisions were susceptible to the public law remedy of judicial review. ${ }^{20}$ The court only assesses the legal aspects of a decision and not the content of policy choices. In other words, a court cannot interfere when an association's decision is 'reasonably arrived at. ${ }^{21}$ This approach stems from the idea that sports associations, similarly to public bodies, have wide autonomy in decisionmaking as long as they observe the law. ${ }^{22}$

\subsection{Germany}

In Germany, there is no disputing that a disciplinary sanction imposed by a sports federation is anything other than an association's decision. The review of disciplinary sanctions, however, has been a constant theme of debate in German legal doctrine since the first review under the new German Civil Code (BGB) took place in 1902. ${ }^{23}$ Historically, the review of associations' decisions has been restricted to a limited test, in recognition of the autonomy of an association. ${ }^{24}$ This autonomy notwithstanding, associations cannot escape external control of their decisions, as the exclusion of such

18 Bradley v Jockey Club [2004] EWHC 2164 (QB) (Richards J) para 37.

19 Bradley (n 18) para 43.

20 cf J Anderson, 'An Accident of History: Why the Decisions of Sports Governing Bodies are not Amenable to Judicial Review' (2006) 35 Common L World Rev 173, 189. Lewis and Taylor have even suggested that the distinction between the private law and public law process has now become irrelevant. Lewis and Taylor (n 15) 164.

21 Lee v Showmen's Guild of Great Britain [1952] 2 QB 329, 333 (Denning LJ).

22 cf Dawkins v Antrobus (1881) 17 Ch D 615; Lee v Showmen's Guild of Great Britain [1952] 2 QB 329.

23 Bürgerliches Gesetzbuch (German Civil Code). W Hadding and F van Look, 'Zur Ausschließung aus Vereinen des Bürgerlichen Rechts' [1988] Zeitschrift für Unternehmens und Gesellschaftsrecht 270-71. cf K Vieweg, 'The Appeal of Sports Law' (2010) 13 <http://www.irut.jura.uni-erlangen.de/Forschung/ Veroeffentlichungen/OnlineVersionFaszinationSportrecht/FaszinationSportrechtEnglisch.pdf> accessed 21 April 2014, who calls the extent of judicial review a classic problem.

24 Bundesgerichtshof (German Court of Federal Justice), II ZR 17/53, 27 February 1954 reported in (1954) 13 BGHZ 5; Bundesgerichtshof (German Court of Federal Justice), II ZR 142/65, 20 April 1967 reported in (1967) 47 BGHZ 381. 
a review is ineffective. ${ }^{25}$ As to the types of decisions that are susceptible to review, somewhat of a distinction can be made.

First, it is opined that factual decisions taken by arbitrators on the field generally should not be reviewed. ${ }^{26}$ In the words of Pfister, 'courts ought to apply legal rules only. ${ }^{27}$ However, disciplinary sanctions are always susceptible to review. A review is generally only permitted after the internal appeal remedies have been exhausted. The German Court of Federal Justice (BGH) has given two reasons for this approach. Pending the final decision of the competent bodies of the association, it must be avoided that the courts (1) are unnecessarily called upon and (2) prematurely intervene in the autonomy of the association. ${ }^{28}$ Over time, the scope of the review has been developed in case law and now extends to whether the imposed measure has a legal basis in the articles of association, whether the prescribed disciplinary procedure has been complied with, whether the respective regulations are consistent with state law and good morals, and whether the imposed sanction is not grossly unreasonable or arbitrary. ${ }^{29}$ Additionally, in order to prevent associations from basing their decisions on underlying facts that, according to the law, could not have been objectively determined, the establishment of facts is also subjected to review. ${ }^{30}$

Another important development with regard to sports is the further extension of the scope of review of decisions taken by associations holding a monopoly position. ${ }^{31}$ Despite the view that the disciplinary sanction is based upon the free subordination of the members, the $\mathrm{BGH}$ has acknowledged that there are numerous situations in which this freedom is actually a fiction, including in the case of regional and national

25 Bundesgerichtshof (German Court of Federal Justice), II ZR 137/57, 26 February 1959 reported in (1959) 29 BGHZ 352, 354; Bundesgerichtshof (German Court of Federal Justice), II ZR 11/94, 28 November 1994 reported in (1994) 128 BGHZ 93, 109.

26 S Krieger, Vereinsstrafen im Deutschen, Englischen, Französischen und Schweizerischen Recht. Inbesondere im Hinblick auf die Sanktionsbefugnisse von Sportverbänden (Duncker \& Humbolt 2003) 133-38; B Pfister, 'Sportregeln vor Staatlichen Gerichten' [1998] Sport und Recht 221; J Räker, Grundrechtliche Beziehungen Juristischer Personen im Berufssport (Duncker \& Humbolt 2008) 221-23.

27 Pfister (n 26) 222.

28 Bundesgerichtshof (German Court of Federal Justice), II ZR 17/53, 27 February 1954 reported in (1954) 13 BGHZ 5, 16; Bundesgerichtshof (German Court of Federal Justice), II ZR 231/64, 6 March 1967 reported in (1967) 47 BGHZ 172, 174; Oberlandesgericht Köln (Cologne Court of Appeal) 19 U 19/05, 23 September $2005<$ http://www.justiz.nrw.de>.

29 Bundesgerichtshof (German Court of Federal Justice), II ZR 138/82, 30 May 1983 reported in (1983) 87 BGHZ 337, 343; Bundesgerichtshof (German Court of Federal Justice), II ZR 17/53, 27 February 1954 reported in (1954) 13 BGHZ 5; Bundesgerichtshof (German Court of Federal Justice), II ZR 121/55, 4 October 1956 reported in (1956) 21 BGHZ 370; Bundesgerichtshof (German Court of Federal Justice), II ZR 137/57, 26 February 1959 reported in (1959) 29 BGHZ 352; Bundesgerichtshof (German Court of Federal Justice), II ZR 231/64, 6 March 1967 reported in (1967) 47 BGHZ 172; Bundesgerichtshof (German Court of Federal Justice), II ZR 142/65, 20 April 1967 reported in (1967) 47 BGHZ 381.

30 Bundesgerichtshof (German Court of Federal Justice), II ZR 138/82, 30 May 1983 reported in (1983) 87 BGHZ 337.

31 Specifically named in Staudinger Kommentar as one of the issues in association law: G Weick, J. von Staudingers Kommentar zum BGB. Buch 1. Allgemeiner Teil, Neubearbeitung (De Gruyter 2005) Vorbem zu $\S 21$, Rdnr. 5 . 
sports federations. ${ }^{32}$ In order to tackle this issue, the BGH ruled that, in cases where an association holds a preponderance of power in a specific economic or social field and the member is dependent on the membership, decisions and/or sanctions do not only have to be in accordance with good faith ( $\$ 242 \mathrm{BGB}$ ) but also be justified by objective reasons. $^{33}$

\subsection{Switzerland}

In Switzerland, the main remedy against a decision or sanction taken by a sports organisation is a complaint based on article 75 of the Swiss Civil Code (CC). ${ }^{34}$ According to this provision, decisions that breach the law or the articles of association can be challenged by each member who did not consent within a month. This right of action is by law and replaces certain legal effects if the appeal is successful. ${ }^{35}$ However, the reviewing instance can only quash the decision and not amend it. As in Germany and France, decisions made on the field of play are generally beyond review. ${ }^{36}$ In addition, as in all other jurisdictions, this action is only open after internal appeal remedies have been exhausted. ${ }^{37}$

The purpose of article $75 \mathrm{CC}$ is to the protect members and otherwise adhered athletes and clubs ${ }^{38}$ from the abuse of the autonomy that is granted to associations. ${ }^{39}$ In this light, the scope of the review is limited to a test of whether the decision breaches the law or the articles of association. Hereto, the court first reviews whether the sanction has a legal basis in the articles of association and whether the prescribed disciplinary

32 Bundesgerichtshof (German Court of Federal Justice), II ZR 138/82, 30 May 1983 reported in (1983) 87 BGHZ 337, 344; Bundesgerichtshof (German Court of Federal Justice), II ZR 54/98, 23 November 1998 reported in (1998) $140 \mathrm{BGHZ} 74$.

33 Bundesgerichtshof (German Court of Federal Justice), II ZR 43/87, 19 October 1987 reported in (1987) 102 BGHZ 265; Bundesgerichtshof (German Court of Federal Justice), II ZR 311/87, 24 October 1988 reported in (1988) 105 BGHZ 306; Oberlandesgericht Frankfurt (Frankfurt Court of Appeal), 13 W 29/00, 18 May 2000; Landgericht Freiburg (Freiburg District Court) 14 O 46/12, 15 May 2012.

34 This provision is a lex specialis of the general provision contained in art 20 Swiss Code of Obligations (CO), according to which a contract is null and void if against the law or morality. Legal action can be based on art $20 \mathrm{CO}$ independently of art 75 CC. See H M Riemer, Die Vereine. Berner Kommentar, Band I/3, 2er Teilband (Stämpfli 1990) art 75, para 113.

35 H Fenners, Der Ausschluss der Staatlichen Gerichtsbarkeit im Organisierten Sport (Zurich 2006) 65; D Oswald, Associations, Fondations, et Autres Formes de Personnes Morales au Service du Sport (2010) Savoirs Sportifs vol 2 113ff.

36 Bundesgerichtshof (Swiss Federal Supreme Court), 118 II 12, 25 March 1992. See also Oswald (n 35) 151-54.

37 Bundesgerichtshof (Swiss Federal Supreme Court), 118 II 12, 25 March 1992, para 3.

38 In the Gundel case, the Swiss Federal Supreme Court held that this remedy is also open to so-called indirect members, ie an athlete or club who is a member of the national, but not the international, federation. Gundel, Bundesgerichtshof (Swiss Federal Supreme Court), 119 II 271, 15 March 1993, para 3b. See also Fenners (n 35) 71-73. See for indirect membership, van Kleef (n 16) 35-37.

39 Oswald (n 35) 114. 
procedure has been complied with. ${ }^{40}$ Regarding the merits of the decision, doctrinal opinion states that the court can only review whether the sanction is rechtsmisbrauchlich, ie whether there is a manifest abuse of a right. ${ }^{41}$ There is manifest abuse if an association acts contrary to general principles of law, such as equal treatment or proportionality.

Independently from the remedy of article $75 \mathrm{CC}$, a sanction can be challenged if it breaches certain other legal provisions, most notably articles 27 and 28 CC. Based on these provisions, a member can take legal action if the sanction wrongfully infringes his personality rights. In general, a disciplinary sanction that suspends an athlete, for breaching doping regulations for example, infringes his personality rights. The term personality rights refers to fundamental rights of an individual that are intrinsic to his being such as the right to life, physical integrity, religion, privacy, honour and also to freely choose one's profession-for instance to be a professional athlete. ${ }^{42}$ However, a violation of personality rights is only sanctioned if the violation is unlawful. A violation is deemed legal if the breach is justified by the consent of the victim, a predominant private or public interest or by the law. In the sports context, the fight against doping has been considered to be such a predominant interest that it justifies the violation of the personality rights of an athlete through a sanction. ${ }^{43}$

\subsection{France}

Unlike in the other countries researched, in France a disciplinary sanction imposed by a national federation is qualified as an administrative act and can therefore only be reviewed by the administrative courts. Traditionally, this review has been quite restrained with the courts only reviewing whether the associations' rules were not unreasonably applied. ${ }^{44}$ However, before the court proceeds to the review of the sanction, a number of formal requirements are applied in a rigorous manner. First, the person submitting the request for review has to have sufficient interest. Naturally, the person sanctioned will meet this requirement. However, in some cases, a disciplinary sanction imposed can seriously affect third parties such as an athlete's club or the league. Nevertheless, the Conseil d'Etat has limited the circle of appellants to the person subjected to the sanction. ${ }^{45}$ In addition, the French courts will not review referees' field of play decisions. ${ }^{46}$ As with all administrative acts, the decision to impose a disciplinary sanction must also be taken by the competent

40 Riemer (n 34) art 75, para 96ff.

41 ibid art 75, para 25. See also C Fuchs, Rechtsfragen der Vereinsstrafe: Unter besondere Berücksichtigung der Verhältnisse in Sportverbänden (Zurich 1999) 144 and authors cited there.

42 A Büchler and M Frei, ZGB Kommentar (2011) art 28, para $3 \mathrm{ff}$.

43 Bundesgerichtshof (Swiss Federal Supreme Court), 134 III 193, 23 August 2007, para 4.6.3.2.2.

44 J P Karaquillo, 'Le Pouvoir Disciplinaire dans Lassociation Sportive' [1980] Rec Dalloz 115, 122.

45 Conseil d'Etat (French Administrative Court), 3 April 1987, no 80239, <www.conseil-etat.fr> accessed 20 April 2015. See also G Simon, Puissance sportive et ordre juridique étatique (Paris 1990) 284.

46 Mantes-la-Ville, Conseil d'Etat (French Administrative Court), 13 June 1984 reported in [1984] Rec Lebon 218. 
body and meet the applicable procedural and form requirements. ${ }^{47}$ Finally, French administrative courts will only proceed to a review after the internal appeal remedies have been exhausted. ${ }^{48}$ Part of this internal appeal remedy is conciliation by the Comité national olympique et sportif français (CNOSF). ${ }^{49}$

The merits of the decision are reviewed in a somewhat stricter manner than in the other jurisdictions. Under French law, the scope of review not only includes the facts underlying the sanction (contrôle de l'appréciation des faits), but also the adequacy of the measure taken. ${ }^{50}$ In cases where a sanction is based on a so-called 'faute sportive', the court only verifies the facts and whether the sanction complies with the law. ${ }^{51}$ However, in cases where the sanction is based on actions that are deemed contrary to a sport's ethics or the interests of the association, the court's review extends further, as it has to interpret the facts for itself. With regard to the adequacy of the measures taken, the court reviews whether these are not manifestly disproportionate or excessive in relation to the goals pursued. ${ }^{52}$ For example, in a case where a young judoka had received a life-time ban on joining a judo club after sexually assaulting two other minors, the Conseil d'Etat held that considering the age of the athlete at the time of his crime and the severity of the penalty, the sanction was disproportionate. ${ }^{53}$ In addition, as administrative acts, disciplinary sanctions are reviewed against the general norms and principles of administrative law, including abus de droit and détournement de pouvoir.

\subsection{Summarising remarks}

The scope of review of disciplinary sanctions in sports is similarly limited in all five countries. Sports organisations-whether governed by private law or public laware granted a large margin of appreciation in the application of their regulations. The specific wordings differ across the jurisdictions, but decisions that are reasonably arrived at and not contrary to the law, which includes good morals, good faith, etc, seem to be virtually untouchable. Even in Germany, where monopoly organisations such as national sports federations are controlled in a stricter manner, the test remains marginal. Only

47 Hechter, Conseil d'Etat (French Administrative Court), 19 December 1980 reported in [1980] Rec Lebon 488. See also Simon (n 45) 287-89; Krieger (n 26) 124-27.

48 Landmark decision: Association Hand-ball Club de Cysoing, Conseil d'Etat (French Administrative Court), 13 June 1984 reported in [1984] Rec Lebon 217, note Morange. See also Toulouse Football Club, Conseil d'Etat (French Administrative Court), 25 June 2001 reported in [2001] Rec Lebon 281; Fédération Française de Judo, Kendo, Jujitsu et Disciplines Associées, Conseil d'Etat (French Administrative Court), 28 November 2007 reported in [2007] Rec Lebon 457.

49 Code du Sport (France) art R.141-5: 'La Saisine du Comité à Fin de Conciliation Constitue un Préalable Obligatoire à Tout Recours Contentieux, Lorsque le Conflit Résulte d’une Décision, Susceptible ou non de Recours Interne, Prise Par Une Fédération dans Lexercice de Prérogatives de Puissance Publique ou en Application de ses Statuts'.

50 Simon (n 45) 291.

51 Bentejac, Conseil d'Etat (French Administrative Court), 16 January 1985 reported in [1985] Rec Lebon 11.

52 Simon (n 45) 296.

53 Conseil d'Etat (French Administrative Court), 28 November 2007 reported in [2007] Rec Lebon 457. 
in France, perhaps, does the scope of the review extend a little further, as it also tests against general principles of administrative law and interpretation of the facts. However, whether this seemingly stricter test would lead to different results in concrete cases than in the other countries is very difficult to foretell. ${ }^{54}$

When a sanction is reviewed by a national court, the interrelation between national law and the private enforcement of the regulations of sports organisations has proved to be subtle. Nevertheless, the rules of national law form a safeguard for athletes and clubs against arbitrary and unlawful application of sports federations' regulations and ensure that fundamental principles of law are applied.

\section{Arbitration of disputes relating to disciplinary sanctions in sports}

Although review before a national court is a logical default option for an athlete or club to challenge a disciplinary sanction, practice shows it is often required to take another path. Many national sport federations and virtually all international sport federations provide that disputes are to be settled in arbitration. The first part of this section therefore analyses the requirements for arbitration in sports-related matters. In 'international' cases-where the sanction is imposed by the international sports federation-it is generally the CAS that reviews the sanction. The goal of arbitration is to render a final decision. However, in order to supervise this form of private dispute resolution, national laws provide that an arbitral award can be challenged before a national court. The second part of this section discusses the circumstances under which arbitral awards-CAS awards in particular-can be overturned by a national court.

\subsection{Requirements for arbitration in sports-related matters}

Arbitration is a complex legal concept, which is exemplified by the lack of a single definition. There is, however, more or less of a consensus about what constitutes arbitration. It is 'a process by which parties consensually submit a dispute to a nongovernmental decision-maker, selected by or for the parties, to render a binding decision resolving a dispute in accordance with neutral, adjudicatory procedures affording each party an opportunity to present its case. ${ }^{55}$ The following will focus on the various requirements that national laws impose on the review of sports disciplinary sanctions in arbitration. ${ }^{56}$

54 Krieger made an attempt at such an analysis on the basis of the Modahl case. See Krieger (n 26) 173-75.

55 G B Born, International Arbitration: Law and Practice (Kluwer 2012) 4.

56 See, for in depth studies of arbitration of sports-related disputes in general, F Oschütz, Sportschiedsgerichtsbarkeit. Die Schiedsverfahren des Tribunal Arbitral du Sport vor dem Hintergrund des schweizerischen un Deutschen Schiedsverfahrensrecht (Duncker \& Humblot 2005); A Rigozzi, Larbitrage International en Matière de Sport (Helbing \& Lichtenhahn 2005). 


\section{(i) The arbitration law}

An arbitration procedure is governed by national private law in the form of the applicable arbitration law, which is not to be confused with the substantive law that governs the dispute. Although virtually every state has its own individual arbitration law, they generally all govern the same issues, including the validity of the arbitration agreement, the arbitration procedure and the award. ${ }^{57}$

The question as to which arbitration law applies usually does not arise when the dispute is between parties in the same jurisdiction. For example, an arbitration between a German football club and the German Football Association (DFB) will be governed by the German arbitration law, which is set out in Book 10 of the German Code of Civil Procedure (ZPO). With regard to international arbitration procedures, however, the applicable arbitration law is virtually always the law of the seat of the arbitration. ${ }^{58}$ The seat is the geographical location to which the arbitration is tied and is often specified in the arbitration clause, for example 'this arbitration will be governed by Dutch law'.

When a sanction is imposed by an international sports federation, the regulations of those organisations generally provide that the decision can be reviewed by the CAS. The CAS is an independent institution that resolves legal disputes in the field of sport through arbitration or mediation. It was originally conceived to deal with disputes arising during the Olympics and was established as part of the IOC in 1984. After the impartiality and independence of the CAS were called into dispute in the famous Gundel case, the CAS was reformed to become an independent institution. ${ }^{59}$ Its jurisdiction is limited to ruling solely on disputes connected with sport, which can be of a disciplinary or a commercial nature. In disciplinary cases, it acts as an appeal instance, whereas in commercial disputes, it acts a court of sole instance. ${ }^{60}$ Without exception, the seat of the CAS and each arbitration panel is Lausanne, Switzerland. ${ }^{61}$ This results in the applicability of Swiss arbitration law, articles 176-94 of the Swiss Private International Law Act (PILA), on all cases that are brought before the CAS.

57 B Born, International Commercial Arbitration: Commentary and Materials (2nd edn, Kluwer 2001) 26-28; Rigozzi (n 56) 193.

58 G Kaufmann-Kohler and A Rigozzi, Arbitrage international. Droit et pratique à la lumière de la LDIP (2nd edn, Weblaw-Schulthess 2010) 45; Born, International Arbitration: Law and Practice (n 55) 112. See also F Russell, J Gill and D St John Sutton, Russell on Arbitration (22nd edn, Thomson Sweet \& Maxwell 2003) s 2-099.

59 Gundel, Bundesgerichtshof (Swiss Federal Supreme Court), 119 II 271, 15 March 1993. The Swiss Federal Supreme Court recognised the CAS as a true court of arbitration, noting that the CAS was not an organ of the federation that had imposed the sanction at issue and that it did not receive instructions from this federation. However, the court noted the strong links between the CAS and the IOC, therefore the independence of the CAS could be questioned in cases where the IOC would be one of the parties.

60 CAS Code, art R27.

61 ibid art R28. 


\section{(ii) The arbitration agreement}

The legal foundation for arbitration is formed by contract, ie the arbitration agreement. Such an agreement expresses the will of the parties to arbitrate their current or future disputes while at the same time renounces the right to bring the case before a state court. This last function is very important as the constitutional right of effective access to the courts has to be relinquished voluntarily. ${ }^{62}$ Arbitration agreements are often formed by a separate provision or clause in a contract. In organised sports, the arbitration agreement ordinarily takes the form of an arbitration clause in the regulations of the sports organisation. Many national and almost all international sport federations impose such arbitration clauses upon their adhered clubs and athletes who are bound through their membership or a license. The validity of such a clause must be reviewed under the applicable arbitration law. Naturally, this test is influenced by the prevailing views on general concepts of law in each country.

Generally, the validity of arbitration clauses in the regulations of sports federations is accepted in four of the five researched jurisdictions. ${ }^{63}$ This is in line with European case law and the dominant view in the literature, according to which adhering to an association-or other legal entity-implies the acceptance of an arbitration clause incorporated in the regulations of the said entity. ${ }^{64}$ In France, however, a disciplinary sanction imposed by a national sports federation is qualified as an administrative act, which cannot be reviewed in an arbitration procedure.

However, the validity of these agreements between sports organisations and their adhered athletes and clubs can potentially be affected by two issues. The first issue is caused by the fact that in many cases clubs and/or athletes are not directly subordinated to the regulations of their international federation. As a result, the arbitration clause is often part of the regulations of the international federation that the club or national federation only refers to. This raises the question of whether the written form requirement of the arbitration agreement-which applies in all countries-has been met. In England, the law expressly provides that a reference to a written document containing an arbitration clause, constitutes an arbitration agreement. ${ }^{65}$ Current case law seems to suggest, however, that a general reference, without expressly mentioning the arbitration clause is not sufficient, unless special circumstances exist. Such circumstances

62 ECHR, art 6; Grondwet (Netherlands Constitution), art 17. See also H J Snijders, Groene Serie Burgerlijke Rechtsvordering. Boek IV (2011) n 1.

63 England: Stretford v Football Association Ltd [2007] EWCA Civ 238. Germany: \$1066 ZPO; Weick (n 31) $\$ 25$, para 24; Landgericht Dortmund [Dortmund District Court], 13 O 113/08 Kart., 16 October 2008 <http://www.justiz.nrw.de>. Netherlands: Dutch Code of Civil Procedure (Rv), art 1020(5); Snijders (n 62) art 1020, notes 8-9. Switzerland: Rigozzi (n 56) 414.

64 Case C-214/89 Powell Duffryn v Petereit [1992] ECR I-01745. See also Kaufmann-Kohler and Rigozzi (n 58) 117; Jochen Kotzenberg, Die Bindung des Sportlers an Private Dopingregeln und Private Schiedsgerichte (Nomos 2007) 128-29.

65 Arbitration Act (UK), 1996 s 6(2). 
can, however, be formed by industry use of standard documents. ${ }^{66}$ It can be assumed that arbitration clauses in sports regulations constitute such industry use. ${ }^{67}$ Similarly, German law does not always require a specific reference, for instance when parties are conscious of the arbitration clause in the referenced document. ${ }^{68}$ In the Netherlands, this issue has yet to be addressed, ${ }^{69}$ while in Switzerland, consistent case law of the Federal Supreme Court holds that a global reference to an arbitration clause contained in the regulations of a sports federation suffices to create a valid arbitration agreement. ${ }^{70}$ Nevertheless, many international sports federations seated in Switzerland now make use of competition entry forms and licenses that include an arbitration clause. This practice further safeguards the risk of a foreign court declaring itself competent to settle the dispute because it considers the arbitration agreement void for not meeting the written form-requirement. ${ }^{71}$ This holds true especially for courts outside of Europe as, in light of the legal systems discussed above, it seems unlikely that a European court would declare itself competent based on this ground.

The second issue, which has been debated extensively in the literature, is whether arbitration agreements incorporated into regulations or competition entry forms still qualify as consensual. ${ }^{72}$ In other words, if so-called 'forced' arbitration-or in German: Schiedszwang - is not contrary to the law. As mentioned above, the concept of arbitration traditionally involves an agreement between parties to have disputes decided by a third person. However, modern arbitration has evolved beyond this notion and there are now many forms of arbitration where there is a prominent inequality between the parties, for instance in labour and consumer matters. With regard to clubs and athletes, they are generally bound through a subordinate membership or other relationship and not by contract. ${ }^{73}$ Nevertheless, with regard to the arbitration agreement between an athlete or

66 See Russell, Gill and St John Sutton (n 58) ss 2-059-2-061 and the cases cited.

67 cf, for instance, Sir A Clarke MR who stated: '[a]n arbitration clause has become standard in the rules of sporting organisations like the FA': Stretford $v$ Football Association Ltd [2007] EWCA Civ 238, para 49.

68 In case the referenced document is considered to contain general terms (AGB), a separate document is nevertheless needed. See Bundesgerichtshof [German Court of Federal Justice], III ZR 30/91, 3 December 1992 reported in [1993] NJW 1798; Oschütz (n 56) 194-95.

69 However with regard to an arbitration clause in a collective labour agreement (CAO), the Dutch Supreme Court ruled that an untied employee was bound to this clause as it was agreed that the CAO rules were applicable on his individual contract. No express consent was necessary. ABN AMRO/Teisman, Hoge Raad (Dutch Supreme Court), 17 January 2003 reported in [2004] NJ 280.

70 Nagel v FEI, Bundesgerichtshof (Swiss Federal Supreme Court), 4C.44/1996, 31 October 1996; Roberts v FIBA, Bundesgerichtshof (Swiss Federal Supreme Court), 4P.230/2000, 7 February 2001. However, a reference to a document containing an arbitration clause in a competition entry form does not extend to disputes outside of this specific competition: $A v W A D A$, Bundesgerichtshof (Swiss Federal Supreme Court), 4A_358/2009, 6 November 2009.

71 Rigozzi (n 56) 420.

72 See for an overview on this debate, Rigozzi (n 56) 422ff and references cited.

73 Only in England is the relationship between sports organisations and their members qualified as contractual. However, it has been suggested that this contract is in reality a fiction, as there is no choice but to enter into it (see further: van Kleef (n 16) 33-35). In addition, there are situations where an athlete or club is bound by a (competition) licence contract. 
club and their governing bodies, it can be argued that the consent stems from the "pacte social' with the sports organisation that is formed when one chooses to become affiliated. ${ }^{74}$ In the Netherlands, no sports-specific case law on this issue exists. Nevertheless, Meijer has suggested that the act of accession to an association implies the acceptance of the arbitration clause. ${ }^{75}$ In English case law, it was considered that '[such clauses] have to be agreed to by anyone (...) who wishes to have a players' licence, but it does not follow that the arbitration agreement contained in them was required by law or compulsory. ${ }^{76}$ The same view can be found in Swiss literature, where it is maintained that the practice of incorporated arbitration clauses is in principle not an obstacle to the voluntary character of arbitration. According to both Baddeley and Rigozzi, 'lobjet de la relation sociale étant, en règle général, un droit à la disposition des parties, il s'ensuit qu'il peut être soumis à l'arbitrage. ${ }^{77}$ According to German case law, an arbitration agreement laid down in an organisation's regulations is considered binding as all members are subordinate to them. ${ }^{78}$ Moreover, the acceptance of this practice in German literature is based on the fact that it does not obstruct the member's right to end his membership. ${ }^{79}$ Furthermore, in the commentary on the Bill that modernised the arbitration chapter in the ZPO, it is argued that inequality of the parties is not by itself reason enough to deem an arbitration agreement void. ${ }^{80}$ However, in a recent decision of the Munich District Court on a claim for damages resulting from a doping ban, the arbitration agreements between German speed skater Claudia Pechstein and the national and international skating federation were found invalid based on the structural imbalance (strukturelles Ungleichgewicht) between the athlete and the federations who formed a monopoly. The Court considered that, without signing the agreements, the athlete would have been unable to pursue her career and the agreements were thus not entered into voluntarily. ${ }^{81}$ This view was, however, nuanced by the Munich Appeal Court, who considered in an interim judgement that the issue is not the imbalance between the parties as such, but rather whether this imbalance prevents the athlete from access to a truly neutral arbitration procedure. ${ }^{82}$ Pending a

74 cf Rigozzi (n 56) 426.

75 G J Meijer, Overeenkomst tot Arbitrage (Kluwer 2011) 503.

76 Stretford v Football Association Ltd [2007] Bus LR 1052 [49].

77 Rigozzi (n 56) 367, citing M Baddeley.

78 Landmark decision Bundesgerichtshof (German Court of Federal Justice), II ZR 124/95, 29 March 1996 reported in (1996) 132 BGHZ 278, 284-285, para 5. See also Oberlandesgericht Düsseldorf (Dusseldorf Court of Appeal), I-16 U 95/98, 14 November 2003.

79 H Hilpert, Das Fußballstrafrecht des Deutschen Fußball-Bundes (DFB) (De Gruyter 2009) 253, citing Haas in E Reschke, U Haas and T Haug (eds), Handbuch des Sportrechts B II, Rn. 186.

80 German parliamentary documentation, BT Drucksache 13/5274, 34.

81 Landgericht München (Munich District Court), 37 O 28331/12, 26 February 2014.

82 Oberlandesgericht München (Munich Appeal Court), U 1110/14 Kart, 15 January 2015. According to the Court, at the time of the Pechstein procedure the CAS did not meet this requirement with regard to the selection of arbitrators where the national governing bodies were favoured. Since 2012, the CAS Code no longer requires that the ICAS establishes the list of arbitrators according to a so-called distribution of arbitrators proposed by the sport governing bodies, effectively removing the structural imbalance criticised by the German court. 
final decision from the BGH, it seems that as long as sports arbitration constitutes a valid alternative to the national justice system it will remain the default option for the review of disciplinary sanctions.

\section{(iii) Arbitrability}

There are disputes that involve such sensitive public policy issues that it is felt that they should only be dealt with by state courts. ${ }^{83}$ A dispute can be deemed 'non-arbitrable' because of its perceived public importance or a felt need for formal judicial procedures and protections. For example, various countries refuse to allow arbitration of disputes concerning employment, intellectual property, real estate or family law. ${ }^{84}$

As with the assessment of the validity of the arbitration agreement, the question of whether disciplinary sanctions can be the subject of an arbitration procedure is answered according to the applicable arbitration law. The provisions in the arbitration laws of the four countries provide, however, no clear answer. In Germany, the Netherlands and Switzerland, the respective provisions are formulated in very general terms. ${ }^{85}$ The English Arbitration Act 1996 lacks a provision on this subject altogether and the English courts approach issues of arbitrability case by case, considering whether the matters in dispute 'engage third party rights or represent an attempt to delegate to the arbitrators what is a matter of public interest which cannot be determined within the limitations of a private contractual process. ${ }^{86}$ However, there are no disputes that will automatically fall outside of this scope.

In the literature, the arbitrability of the review of disciplinary sanctions has mainly been debated in Switzerland. ${ }^{87}$ Opponents argue that these disputes are, in principal, contrary to public policy as a result of the monopoly position of sports organisations who unilaterally enforce their rules. ${ }^{88}$ Nevertheless, case law, legal literature and practice show that the review of disciplinary sanctions imposed by sports federations upon their members or otherwise affiliated clubs or athletes by means of arbitration is generally accepted in Switzerland, as well as in England and Germany. ${ }^{89}$ In the Netherlands, it remains unclear whether disciplinary sanctions of sports organisations

83 L A Mistelis, 'Is Arbitrability a National or an International Law Issue?' in L A Mistelis and S L Brekoulakis (eds), Arbitrability: International and Comparative Perspectives (Kluwer 2009) 1, 4.

84 Born, International Commercial Arbitration: Commentary and Materials (n 57) 244.

85 Germany: ZPO, \$1030. Netherlands: Rv, art 1020. Switzerland: Swiss Code of Civil Procedure (CPC), art 354 (for national arbitrations) and Swiss PILA, art 177 (for international arbitrations).

86 Fulham Football Club Ltd v Richards [2011] EWCA Civ 855, para 40.

87 See, for an extensive overview of the debate, Rigozzi (n 56) 367ff.

88 P Meier and C Aguet, 'L'arbitrabilité du Recours Contre la Suspension Prononcée par une Fédération Sportive International' [2002] Journal des tribunaux I 55.

89 England: Stretford $v$ Football Association Ltd [2007] EWCA Civ 238, paras 49-54. Germany: Kotzenberg (n 64) 114-22; Oschütz (n 56) 155. Switzerland: M Baddeley, Lassociation Sportive Face au Droit. Les limites de son Autonomie (Helbing \& Lichtenhahn 1994) 261; Fenners (n 35) 187-97; Rigozzi (n 56) 367, 382. Another indication of this acceptance is provided by the various sports arbitration tribunals that have been set up in the respective countries. 
can be reviewed in arbitration since the Dutch Supreme Court ruled that a claim to void a legal entity's resolution cannot be decided by arbitrators. ${ }^{90}$ This case dealt with very specific circumstances and the general wording of the court, effectively applying this rule to all legal entities, including (sports) associations, has been scrutinised in the literature. ${ }^{91}$ Regardless of this ruling, the regulations of most national sports federations in the Netherlands completely lack provisions on how to appeal disciplinary sanctions, automatically leaving jurisdiction to the ordinary courts. ${ }^{92}$

\section{(iv) Applicable procedural rules}

National arbitration laws impose hardly any specific procedural requirements on the arbitral proceedings. ${ }^{93}$ Therefore, in most cases the parties are entirely autonomous in deciding the procedural rules that apply. Sometimes, however, procedural rules are imposed. For example when parties opt for institutional arbitration-such as before the CAS-the procedural rules are often imposed by the institution. In the absence of agreement between the parties regarding the applicable procedural rules, national arbitration laws provide the arbitrators with the discretion to establish these. ${ }^{94}$ When an arbitration procedure takes place before the CAS, it is the Code of Sports-related Arbitration (hereafter: the Code) that provides the applicable procedural rules. The Code was first enacted in 1994. With its first revision in 2004, certain long-established principles of CAS case law and practices consistently followed by the arbitrators and the Court Office were incorporated. ${ }^{95}$

\section{(v) Applicable substantive rules}

To settle the dispute, the arbitrators will generally decide according to the law chosen by the parties, or in absence thereof, in accordance with the laws of that country to which the subject matter of the proceedings has the closest connection. ${ }^{96}$ In many jurisdictions,

90 Groenselect, Hoge Raad (Dutch Supreme Court) 10 November 2006 reported in NJ 2007, 561, note H J Snijders.

91 See H M de Mol van Otterloo, 'Arbitrabiliteit van Vennootschapsrechtelijke Geschillen; het Groenselectarrest' [2010] Ondernemingsrecht 3; E R Meerdink and S Vermeulen, Arbitrage Over Besluiten van Organen van de Vennootschap: Hoog Tijd voor Wetgeving' [2012] Tijdschrift voor Arbitrage 2012/59.

$92 \mathrm{M}$ van Koolwijk, H van Egdom and B Dubois-van Kleef, Tuchtrecht bij Sportbonden: Inventarisatie, Ambitie en Aanbevelingen (Disciplinary law of sports federations: inventory, ambition and recommendations) (2013) <http://www.nocnsf.nl/stream/07.b.-rapportage-tuchtrecht-bij-sportbonden.pdf> accessed 21 April 2014. Only with regard to doping offences, some Dutch federations provide for an appeal to the CAS.

93 Born, International Arbitration: Law and Practice (n 55) 147. England: Arbitration Act 1996 (UK), s 34. Germany: ZPO, \$1042(3). Netherlands: Rv, art 1036. Switzerland: CPC, art 373(1); PILA, art 182(1).

94 England: Arbitration Act 1996 (UK), s 34. Germany: ZPO, \$1042(4). Netherlands: Rv, art 1036. Switzerland: CPC, art 373(2); PILA, art 182(2).

95 The latest version of the Code of Sports-related Arbitration entered into force on 1 March 2013.

96 Germany: ZPO, \$1051. Netherlands: Rv, art 1054. Switzerland: CPC, art 381 (2) (the laws that a court would have applied) and PILA, art 187. In England, the wording of Arbitration Act 1996 (UK), s 46, is a little different, but in conjunction with art 4 of the Rome I Regulation, comes to a similar result. See also J D M Lew and others (eds), Arbitration in England (Kluwer 2013) s 11-11, 209. 
parties are also allowed to agree that their disputes will be settled according to fairness or equity. However, in CAS cases, arbitrators are not allowed to rule according to fairness or equity, even though the Swiss PILA provides for this option. ${ }^{97}$

In cases where the sanction is imposed by a national sports organisation and no choice of law has been made, the applicable law will generally be the law of the country where the organisation is seated, as it will have the closest ties to the dispute, in addition to the applicable regulations. In contrast to the review before a national court, an arbitration panel can be given the power to review the decision of the federation in full, if this follows from the arbitration agreement.

In cases regarding disciplinary sanctions before the CAS, the position of national law is different, as article R58 of the Code emphasises the primary application of sports regulations rather than national law.

The Panel shall decide the dispute according to the applicable regulations and, subsidiarily, to the rules of law chosen by the parties or, in the absence of such a choice, according to the law of the country in which the federation, association or sports-related body which has issued the challenged decision is domiciled or according to the rules of law that the Panel deems appropriate. In the latter case, the Panel shall give reasons for its decision.

The formulation of this provision in the old edition of the Code, which lacked the word 'subsidiarily', led Hascher and Loquin to promote the idea that these regulations can be applied exclusively from any national law. ${ }^{98}$ This view is supported by certain CAS rulings in which the respective panels decided that in the case at hand they did not need national law to come to their decision.

Si les parties nont pas déterminé un droit national applicable, elles sont, en revanche, soumises aux statuts et règlements de la FIBA (...). Le droit fédératif adopté par la FIBA constitue une réglementation de droit privé, ayant une vocation internationale, voire mondiale, à s'appliquer dans le domaine des règles de sport régissant le basketball. Pour résoudre le présent litige, le tribunal arbitral appliquera donc ce droit fédératif, sans recourir à l'application de telle ou telle loi nationale au fond. ${ }^{99}$

However, according to Rigozzi, the suggestion that sports regulations prevail over the parallel applicable national law is difficult to reconcile with the text of the provision. In order for regulations to be exclusively applicable, a supplementary choice of law in favour of these regulations would be needed. ${ }^{100}$ Article R58 of the Code also bears the important consequence that in the absence of a choice of law, it is Swiss substantive law

97 See PILA, art 187(2) and CAS Code, art R.45 a contrario. Contrary to disciplinary cases, arbitrators are allowed, upon the parties' wish, to decide according to equity and fairness in commercial cases that are brought before the CAS.

98 D Hascher and E Loquin, 'Tribunal Arbitral du Sport (TAS). Chronique des Sentences Arbitrales' [2004] Journal du droit International 289, 312.

99 IAAF v CADA and Witteveen, CAS 2002/A/417 \$82-83; and repeated in Amadou Diakite v FIFA, CAS 2011/A/2433 \$14.

100 Rigozzi (n 56) 609. 
that will be applied. As the large majority of international sports organisations are seated in Switzerland, Swiss law is applicable in a majority of cases.

With regard to the applicability of EU law, it must be noted that EU rules that have a direct effect are part of the law of EU Member States and must be applied by the CAS if the chosen law is the law of one of these countries. In sporting matters, such rules include internal market and competition law prohibitions. ${ }^{101}$ When the applicable law is Swiss law, in principle EU law does not need to be considered since Switzerland is not a member of the European Union. However, in case an award is to be executed in an EU Member State or if it affects the EU market, EU law does play a role, considering that the execution of an arbitral award can be stopped if it is contrary to public policy. ${ }^{102}$ Arbitrators have the obligation to ensure an executable award and should thus apply those rules of EU law that constitute rules of public policy in any case in which an award may be required to be enforced in an EU Member State. ${ }^{103}$ In addition, according to the Swiss Federal Supreme Court, it is generally recognised that Swiss civil courts and arbitrators should examine the validity of a contractual agreement affecting the EU market in the light of EU law, even if the parties have contractually agreed to apply Swiss law. ${ }^{104}$

\section{(vi) The scope of review in CAS cases and the arbitral precedent}

In cases where disciplinary sanctions are reviewed before the CAS, the scope of review is not limited. The CAS performs a full review, which is not only based on the applicable regulations and substantive law, but also on arbitral precedent. This notion is paradoxical given that arbitration generally lacks a doctrine of precedent or stare decisis. ${ }^{105}$ Each arbitrator or arbitration panel decides cases autonomously and is not bound by previous decisions from other panels. Nevertheless, the approach in sports arbitration is different; CAS arbitration panels have demonstrated a consistent practice of referring to earlier CAS decisions. ${ }^{106}$

This practice already existed in the early days of the CAS. In 1996, a panel considered that, '[a]lthough we are not obliged to follow the reasoning of a previous Tribunal (especially where it was not essential to the decision which they reached), we are disposed to do so, both out of a sense of comity and because of the desirability of

101 Case C-36/76 Walrave and Koch v UCI [1974] ECR I-01405; Case C-415/93 Bosman [1995] ECR I-04921; Case C-519/04 Meca-Medina [2006] ECR I-06991.

102 New York Convention 330 UNTS 38 (1968) art V(2)(b).

103 Case C-126/97 Eco Swiss v Benetton [1999] ECR I-03055.

104 BGER 1 Civil Court, 13 November 1998, reported in (1999) 17 ASA Bulletin 529, para 1a. See also M Coccia, 'Applicable law in CAS Proceedings: What to do With EU law?' in M Bernasconi and A Rigozzi (eds), Sport Governance, Football Disputes, Doping and CAS Arbitration (Weblaw 2009) 69, 88; A Rigozzi, 'Arbitrage, Ordre Public et droit Communautaire de la Concurrence' (1999) 17 ASA Bulletin 455, 464-65. 105 G Kaufmann-Kohler, 'Arbitral Precedent: Dream, Necessity or Excuse? The 2006 Freshfields Lecture' (2007) 23 Arbitration International 357, 357.

106 L Casini, 'The Making of a Lex Sportiva by the Court of Arbitration for Sport' (2011) 12 German L J 1317 , 1331. As well as to advisory opinions, for instance in AC $v$ FINA, CAS 96/149, 8, para 28. 
consistent decisions of the CAS, unless there were a compelling reason, in the interest of justice, not to do so. ${ }^{, 107}$ In another case, the respective arbitration panel stated that:

in arbitration there is no stare decisis. Nevertheless, the Panel feels that CAS rulings form a valuable body of case law and can contribute to strengthening legal predictability in international sports law. Therefore, although not binding, previous CAS decisions can, and should, be taken into attentive consideration by subsequent CAS panels, in order to help to develop legitimate expectations among sports bodies and athletes. ${ }^{108}$

Since 2003, nearly every award contains one or more references to earlier awards. ${ }^{109}$ This has resulted in the situation that even though there is no such thing as formal 'CAS case law', practice shows that earlier decisions are carefully studied and can therefore influence later cases.

As a result, a virtually coherent body of law seems to have emerged, which various authors have labelled as lex sportiva. ${ }^{110}$ Although the definitions vary in scope, ${ }^{111}$ lex sportiva seems to cover 'anational' rules and general principles of law that fill in the lacunas that the sports regulations leave and which often have a specific connotation in sports law cases. The most significant rule of the so-called lex sportiva is arguably the strict liability rule for doping offences. This rule provides that a doping offence occurs whenever a prohibited substance is found in an athlete's body, irrespective of the athlete's intention or negligence in ingesting the banned substance, for example through a contaminated supplement. Moreover, the application of this rule is so consistent, that any difference with stare decisis has become trivial. The strict application of certain lex sportiva rules results from the need for a uniform and coherent application of the regulatory framework of sports.

As a result of this consistent rule of precedent, the CAS exercises a strong influence on the rules and regulations of sports organisations, most notably on doping regulations but also on rules regarding player transfers and eligibility for international competitions. Furthermore, aside from this-perhaps more implicit-influence on regulations through its awards, the CAS also does not seem to hesitate to give explicit 'advice' on regulations

107 AC v FINA, CAS 96/149, 7, para 19.

108 UCI $v$ Jogert \& NCF, CAS 97/176, para 40. See, for similar wording, IAAF $v$ USA Track \& Field and Jerome Young, CAS 2004/A/628, para 73.

109 Kaufmann-Kohler (n 105) 357, 365.

110 E Loquin, 'Lutilisation par les Arbitres du TAS des Principes Généraux du droit et le Développement d'une lex Sportiva' in A Rigozzi and M Bernasconi (eds), The Proceedings Before the Court of Arbitration for Sport (Schulthess 2007) 99; K Foster, 'Lex Sportiva and Lex Ludica: the Court of Arbitration for Sport's Jurisprudence' in Ian S Blackshaw and others (eds), The Court of Arbitration for Sport 1984-2004 (TMC Asser 2006) 420; J A R Nafziger, 'Lex Sportiva' (2004) 1-2 Intl Sports L J 3; J Adolphsen, 'Eine lex Sportiva für den Internationalen Sport?’ [2002] Die Privatisierung des Privatrechts-rechtliche Gestaltung ohne staatlichen Zwang 281; Casini (n 106) 1317.

111 From including only those principles that are developed by the CAS, according to Nafziger, to 'lensemble des règles de droit anational qu'il convient d'appliquer pour affranchir le droit applicable au fond dans les litiges sportifs de tout emprise des différents droits nationaux', according to Rigozzi: see J A R Nafziger, 'Lex Sportiva and CAS' in Ian S Blackshaw and others (eds), The Court of Arbitration for Sport, 1984-2004 (n 110) 409. 
it deems unsatisfactory. For example, in $A C v$ FINA, the CAS noted that it would clearly be desirable if the FINA Medical Rules were revised so as to attach a flexible sanction to a failure to comply with an important and mandatory obligation of this character.'.12 Nevertheless, in their reasoning, the CAS arbitrators have to take into account the fact that their award-like all arbitral awards_runs the risk of being challenged in court.

\subsection{Challenging the arbitral award}

The purpose of arbitration is to obtain a final and binding decision. Nevertheless, most national arbitration laws provide the option to challenge or annul an arbitral award in court. ${ }^{113}$ National law thus interferes with the completely private regulatory framework of sports organisations when an arbitral award, in which the disciplinary sanction is confirmed or quashed, is being reviewed by a national court. The following discusses the rules according to which an arbitral award can be overturned, showing the limits of the review of private regulations in the private sphere. At the same time, it becomes apparent that on an abstract level, the review of arbitral awards bears close similarities to the marginal review of disciplinary sanctions by national courts.

\section{(i) Grounds for overturning an arbitral award}

When an award is annulled or set aside, the case will generally be referred back to either the arbitration instance or, if the arbitration panel lacked jurisdiction, to the national court that should have reviewed the sanction in the first place. Unlike the arbitration laws in England, Germany and the Netherlands, the Swiss PILA provides only one instance to challenge the award-the Swiss Federal Supreme Court. ${ }^{114}$ The available grounds upon which an award can be challenged logically depend on the applicable arbitration law. In most countries, arbitral awards can only be reversed by a national court if they are fundamentally flawed. ${ }^{115}$ Such fundamental flaws are mainly flaws of a procedural nature and are similar across the laws of the four jurisdictions.

First, an arbitration award may be annulled if there is no valid arbitration agreement or if the tribunal wrongly assumed jurisdiction to decide on the matter. ${ }^{116} \mathrm{~A}$ second ground for appeal is if the constitution of the arbitral tribunal was irregular. ${ }^{117}$ For

112 AC v FINA, CAS 96/149, 6, para 9.

113 Some arbitration laws provide for an opt-out of the possibility to challenge the award. For instance in England: Arbitration Act 1996 (UK), s 69. In Switzerland the appeal can be excluded only if both parties are non-Swiss: PILA, art 192(1).

114 Since in France disciplinary sanctions by sports federations cannot be reviewed in arbitration, the overturning of arbitral awards according to French law will not be discussed.

115 Born, International Arbitration: Law and Practice (n 55) 302.

116 England: Arbitration Act 1996 (UK), s 67. Germany: ZPO, \$1059(2)(1)(a). Netherlands: Rv, art 1065(1)(a). Switzerland: PILA, art 190(2)(b); CPC, art 393(b).

117 Germany: ZPO, $\$ 1059(2)(1)(d)$. Netherlands: Rv, art 1065(1)(b). Switzerland: PILA, art 190(2)(a); CPC, art 393(a). In England, irregular constitution of the tribunal can be challenged under the lack of substantive jurisdiction provision in Arbitration Act 1996 (UK), s 67. 
example, if circumstances led to a doubt surrounding the independence of one of the arbitrators. A third ground for appeal common to all jurisdictions is if the tribunal ruled on matters beyond the claims submitted by the parties or if it failed to rule on one of the claims. ${ }^{118}$ Finally, all four jurisdictions include one general or multiple specific grounds regarding the arbitration procedure. For example, both Swiss arbitration laws include a reason for appeal if the equality of the parties or their right to be heard in an adversarial procedure were not respected. In the Netherlands, a separate ground exists if the award has not been signed or motivated. ${ }^{119}$ In England, the failure to comply with the form requirements of the award is mentioned as one of the kinds of serious irregularity. ${ }^{120}$

\section{(ii) A restrictive review of the merits of the award}

In three of the four jurisdictions, the sole substantive ground to overturn an arbitration award is when the award or its results are contrary to public policy. ${ }^{121}$ Only the English Arbitration Act allows for a wider appeal on the merits on points of English law. ${ }^{122}$ However, such an appeal is only admissible with the agreement of all other parties to the arbitration proceedings or with leave of the court. ${ }^{123}$ Often the parties opt out of this possibility to appeal in the arbitration agreement. ${ }^{124}$

The notion of public policy (or in French: ordre public) is both abstract and complex. In the context of this article it suffices to mention that public policy entails the most fundamental principles-both formal and substantive-of a legal order. ${ }^{125}$ For example, fundamental breaches of due process, which most notably include the right to be heard, are generally thought of as being contrary to public policy. ${ }^{126}$ Other fundamental principles of public policy include pacta sunt servanda, rules of good faith and prohibition of discriminatory measures. ${ }^{127}$

In European Union Member States, public policy also includes the fundamental provisions of EU law. In a case where EU competition rules were at issue, the Court of

118 England: Arbitration Act 1996 (UK), s 68(2)(b), (d). Germany: ZPO, \$1059(2)(1)(c). Netherlands: Rv, art 1065(1)(c). Switzerland: PILA, art 190(2)(c); CPC, art 393(c).

$119 \mathrm{Rv}$, art 1065(1)(d).

120 Arbitration Act 1996 (UK), s 68(2)(h).

121 England: Arbitration Act 1996 (UK), s 68(2)(g). Germany: ZPO, \$1059(2)(b). Netherlands: Rv, art 1065(1) (e). Switzerland: PILA, art 190(2)(e). However, CPC, art 393, instead speaks of 'manifest error of law or equity'.

122 Arbitration Act 1996 (UK), ss 69, 82.

123 Arbitration Act 1996 (UK), s 69.

124 For example, when the parties agree to submit disputes to ICC arbitration, rules of which exclude an appeal on a question of law: see ICC Rules, art 34(6).

125 See, on the definition of public policy, H Arfazadeh, Ordre Public et Arbitrage International à Lépreuve de la Mondialisation, (Bruylant 2006) 263-73.

126 Netherlands: Snijders (n 62) art 1065, n 7. Germany: S M Kröll and P Kraft, 'Commentary on the German Arbitration Law', in K-H Böckstiegel, S M Kröll and others (eds), Arbitration in Germany: The Model Law in Practice (Kluwer 2007) 436, 453, para 42. Switzerland: Bundesgerichtshof (Swiss Federal Supreme Court), 132 III 389, 8 March 2006, para 2.2.

127 Kaufmann-Kohler and Rigozzi (n 58) 534-35. 
Justice of the European Union (CJEU) considered that it is in the interest of efficient arbitration proceedings that the annulment of an award should only be possible in exceptional circumstances. It then stressed, however, that article 105 (formerly article 85) constitutes a fundamental provision of community law which, as such, must be regarded as a matter of public policy. As a result,

where its domestic rules of procedure require a national court to grant an application for annulment of an arbitration award where such an application is founded on failure to observe national rules of public policy, it must also grant such an application where it is founded on failure to comply with the prohibition laid down in Article 85(1) of the Treaty. ${ }^{128}$

In short, this entails that when national law provides for annulment of an award because of its incompatibility with public policy, the notion of public policy includes article 105 . According to doctrinal opinion, it can be assumed that this case law is not limited to EU competition law and, on the contrary, entails that all fundamental rules of European community law are part of the public policy of the Member States. ${ }^{129}$ Thus, if an arbitral award results in a situation that is contrary to a fundamental provision of European law the award could be annulled in court based on the violation of public policy. ${ }^{130}$

In comparison, according to Swiss law, the concept of public policy with regard to appeals against arbitral awards is even narrower. The Swiss Federal Supreme Court considers that an award is contrary to public policy, 'si elle méconnaît les valeurs essentielles et largement reconnues qui, selon les conceptions prévalant en Suisse, devraient constituer le fondement de tout ordre juridique. ${ }^{131}$ In other words, public policy covers only those fundamental principles that are widely recognised and that should, according to the prevailing conceptions in Switzerland, be the foundation of any system of law. In contrast to the view of the CJEU, according to the Swiss Federal Supreme Court these fundamental principles do not include provisions of competition law, whether European or Swiss. ${ }^{132}$

This restrictive review of the merits of an arbitral award seems similar to the equally marginal review that national courts apply when they perform the review of a disciplinary sanction. Both the sports federation and arbitral panel are granted wide discretion to decide as they see fit, as long as they stay within the fundamental boundaries of the law.

\section{(iii) The Swiss Federal Supreme Court: the final instance in CAS cases}

Article 191 of the Swiss PILA provides that an arbitral award handed down in Switzerland can be challenged solely before the Swiss Federal Supreme Court. As a result, CAS

128 Case C-126/97 Eco Swiss v Benetton [1999] ECR I-03055, para 37.

129 Snijders (n 62) opschrift, aant. 8; F de Ly, Case note [1999] Tijdschrift voor Arbitrage 100, para 17; Assimakis P Komninos, 'Case note on Case C-126/97 Eco Swiss v Benetton' (2000) 37 CML Rev 459, 473-75.

130 See, on the debate on whether rules of competition law should fall under the scope of public policy, N Shelkoplyas, The Application of EC law in Arbitration Proceedings (Europa Law Publishing 2003) 368-69.

131 Bundesgerichtshof (Swiss Federal Supreme Court), 132 III 389, para 2.2.3.

132 ibid. 
awards are only subjected to a single test before a national court. According to the Swiss PILA, an arbitration award can be challenged: (a) if a sole arbitrator was designated irregularly or the arbitral tribunal was constituted irregularly; (b) if the arbitral tribunal erroneously held that it had or did not have jurisdiction; (c) if the arbitral tribunal ruled on matters beyond the claims submitted to it or failed to rule on one of the claims; (d) if the equality of the parties or their right to be heard in an adversarial proceeding were not respected; or (e) if the award is incompatible with Swiss public policy. Blackshaw states that ground (d) is probably the most important, seeing that 'the CAS bends over backwards in each case to ensure that the parties are properly heard and receive a fair hearing. ${ }^{133}$ The opportunity of appeal notwithstanding, the number of appeals against CAS awards remains limited.

The reticence to appeal is not unlikely to result from the fact that appeals to annul arbitral awards are very rarely accepted when based on the sole substantive ground of infringement of public policy. ${ }^{134}$ In the early days of the CAS, some awards were annulled based on procedural errors. However, as the CAS nowadays pays great attention to its procedure, practically the only ground left to challenge an award is incompatibility with public policy. As mentioned above, in order for an award to be deemed contrary to public policy, it must be breaching a fundamental principle that is deemed to be part of the foundation of the system of law. This is a very high standard to meet and so far only one appeal has ever been successful on this ground.

In the Matuzalem case, football player Matuzalem and his club Real Zaragoza were ordered to pay compensation to the player's former club Shaktar Donetsk for breach of contract after the player's transfer to Real. After both failed to pay on time, the player was banned from any activity in connection with football until the compensation was paid. The Swiss Federal Supreme Court held that such an open-ended playing ban constitutes a severe infringement on the player's personality rights as laid down in article 27(2) of the Swiss Civil Code. ${ }^{135}$ In the absence of legitimate interests by which this infringement could be justified, a breach of public policy was recognised. The case has had a large response from scholars who, among other things, discussed whether Matuzalem has opened the door for further annulments of CAS awards. The majority agree, however, that it seems unlikely that such a door has been opened in light of the exceptional circumstances of this case. ${ }^{136}$ Nevertheless, the CAS has been reminded that

133 I S Blackshaw, Sport, Mediation and Arbitration (TMC Asser 2009) 174.

134 Kaufmann-Kohler and Rigozzi (n 58) 523. See, for a statistical overview, F Dasser, 'International Arbitration and Setting Aside Proceedings in Switzerland: A Statistical Analysis' (2007) 25 ASA Bulletin 444.

135 According to this provision, 'no person may relinquish his freedom or restrict the use of it to a degree which is contrary to law or morals'.

136 'Note: Francelino da Silva Matuzalem v FIFA, Federal Supreme Court of Switzerland, 1st Civil Law Chamber, 4A_558/2011, 27 March 2012' (2012) 4 Revue de l’Arbitrage 860; R Levy, 'Swiss Federal Tribunal overrules CAS award in a landmark decision: FIFA vs Matuzalem' (2012) 1-2 Intl Sports L J 36; L Burger, 'For the First Time, the Supreme Court Sets aside an Arbitral Award on Grounds of Substantive Public Policy' (2012) 30 ASA Bulletin 603. 
the legitimacy of arbitration requires that the most fundamental principles of the legal order be respected at all times.

\subsection{Summarising remarks}

Arbitration is often the mandatory path for athletes or clubs to have a disciplinary sanction legally reviewed. The review itself technically stays in the private sphere, but the proceedings are governed by national law in the form of the arbitration law. Except for in France, the national laws of the countries studied allow disciplinary sanctions to be reviewed in arbitration. With regard to the application of national concepts of private law, such as the validity of the arbitration agreement and the question of arbitrability of the disciplinary sanction, there are no significant differences across the jurisdictions. Disciplinary sanctions can be subjected to arbitration and an agreement between athletes or clubs and sports federations, even if forced, is generally valid. However, it must be noted that the recent developments in Germany could signify a shift in appreciation of such arbitration agreements if confirmed in appeal. The arbitration law also provides guidance as to which regulations and substantive law an arbitration panel ought to decide. In CAS cases, a full review is being performed, not only based on the applicable regulations but also on so-called arbitral precedents from earlier CAS decisions.

Even when a disciplinary sanction is being reviewed through private dispute resolution, there is still the possibility of involving public justice. National arbitration laws provide the option to challenge or annul an arbitral award in court. However, it has become clear that this is not an easy feat. In all countries, grounds for appeal are limited, with the merits of the award only being tested against rules of public policy, which is a very high standard to meet. Finally, in CAS cases, there is only one chance to have the arbitral award reviewed by Switzerland's highest court. However, considering the restrictive grounds for review, the CAS is left with ample room to decide as long as it stays within the boundaries of the fundamental principles of the law.

\section{Concluding remarks}

The creation and enforcement of disciplinary rules in sports takes place on different levels. Although a sports federation can autonomously create its own regulations and enforce them through a private sanctioning system, this application of the rules in the form of a sanction can be tested either before a national court or in arbitration. Upon a closer look at this specific context it has become apparent that in the review of disciplinary sanctions different legal frameworks-of both private rules of sports federations and national law-are connected and interrelate in many ways.

When a disciplinary sanction is imposed, there are two ways to have an external body review the sanction. Unless an arbitration agreement exists, this review is performed by a national court. In this review, the sanction is tested against the regulations and 
the applicable national substantive law. The scope of the review is limited in all the researched countries and generally only checks whether decisions are reasonably arrived at and not contrary to the law. Only in France, perhaps, does the scope of the review extend a little further. In general, however, sports federations are allowed a large margin of appreciation to make decisions.

The alternative is to have the sanction reviewed in arbitration, which is often the mandatory path imposed by the regulations of the sport federation. Although arbitration is a form of private dispute resolution, the proceedings are almost completely governed by rules of national law. This entails the applicability of national concepts of private law, for example regarding the validity of the arbitration agreement and the question of arbitrability of the disciplinary sanction. In addition, the arbitration law prescribes how to determine the procedural and substantive rules that the arbitration panel ought to apply when it reviews the sanction. In contrast to national courts, the arbitration panel can be given the power to carry out a full review, which is the case, for example, when a disciplinary sanction is brought before the CAS.

The arbitral award is not the final step in the process though, as it can still be challenged before a national court. However, in all researched countries grounds for appeal are limited. The restrictions to this review turned out to bear close similarities to the review of national courts when they perform the review of the disciplinary sanction in cases where arbitration is excluded. When an arbitral award is challenged, further interrelations between national law and the regulations of sports federations become apparent. Rules of national law can influence the regulations of sports federations. For example, when an arbitral award is overturned there might be a need to adapt the regulations. In this regard, the significance of the Swiss Federal Supreme Court in the regulation of international sport is undeniable. It the only institution in the position to exercise direct influence on the CAS through its case law. This observation is reinforced by the fact that the CAS seems indeed willing to comply and to act on criticism from the Court. ${ }^{137}$

Finally, this article demonstrated that the legal protection against disciplinary sanctions in sport is approached in much the same manner in the five European legal systems that were included in this exercise. In the Netherlands, England, Germany and Switzerland the dual system of review of disciplinary sanctions takes the same form. Furthermore, the connection between the frameworks of national law and the regulations of sports federations proves to be virtually identical in these countries. France remains the exception where, unlike in the other countries, disciplinary sanctions in sport cannot be reviewed in arbitration. However, regarding the scope of review, French law is not substantively different. After all, in France too, sports federations are allowed considerable discretion to make their own decisions, including decisions in disciplinary matters.

137 See Rigozzi and others, who note that one of the amendments to the Code seems to be the result of a critical remark from the Court (A Rigozzi, E Hasler and B Quinn, 'The 2011, 2012 and 2013 Revisions to the Code of Sports-related Arbitration' [2013] Jusletter 16). 